\title{
Credit Card Literacy Levels And Credit Card Usage Behaviors Of College Students
}

\author{
Cengiz TORAMAN \\ Gaziantep University \\ Department of Business \\ Administration \\ Gaziantep, Turkey \\ ctoraman@gantep.edu.tr
}

\author{
Yunus KILIÇ \\ Gaziantep University \\ Department of Business \\ Administration \\ Gaziantep, Turkey \\ yunuskilic@gaziantep.edu.tr
}

\author{
Mehmet Fatih BUĞAN \\ Gaziantep University \\ Department of Business \\ Administration \\ Gaziantep, Turkey \\ mf.bugan@gmail.com
}

\begin{abstract}
This study aims to determine behaviors of college students regarding use of credit card and their level of credit card literacy. For this end, a survey is conducted with 720 respondents studying in Gaziantep University. According to findings of the study, credit card literacy level of the students is determined as $43 \%$. One of the findings is that credit card literacy level of students differs according to gender and the faculty that they are studying. Also it is observed that students who get a credit card after a conscious reading of credit card agreement and students who regularly pay the debt have a higher level of credit card literacy compared to other students.
\end{abstract}

Keywords: Credit card literacy, credit card behavior, financial literacy

\section{Introduction}

While preparing individual budget one can face with situations where expenditure is greater than income. The solution to this situation, which creates financial difficulty, is to borrow from others or to use a credit. Today, payment instrument, which is used widely and solves this problem easily, is credit cards. Increasing use of credit cards in financial transactions also increased the importance of credit cards in the financial system. Regardless of income level, almost all households have credit cards (Warwick and Mansfield, 2000: 617). Hayhoe et al. (2005), stated that nearly half of the university students have more than one credit card. In recent year's use of credit cards is preferred in daily shopping compared to use of cash (Borzekowski et al., 2006: 10). Özkan (2014) stated that as of $2012,35.13 \%$ of private final goods consumption was done through debit and credit cards (Özkan, 2014: 10). The only reason for increase in the usage of credit cards is not imbalance between income and expenditures. At the same time, pushing up consumer spending appetite through installment payment facility and payment easiness are among the reasons for the increase in the usage of credit cards. Also bank promotions to sell more credit cards to individuals have an effect on this increase.

Credit card usage has advantages and disadvantages depending on the consumer's pattern of use. Prudent and right use of credit card decrease liquidity risk of individuals 
and provide additional resources. However, credit card expenditures, which are unconscious and over budgetary limits, may cause individuals to have excessive debt creating financial difficulties or leading to bankruptcy. Therefore, to decrease credit card indebtedness and to have a conscious usage of credit card, it is necessary for individuals to have information about financial issues and credit card.

Most of the studies in the literature on financial awareness is related to financial literacy (Berlin and Mester, 2004; Wickramasinghe and Gurugamage, 2012: 81). There are several definitions of financial literacy made by different organizations and researchers. For the Organization for Economic Co-operation and Development (OECD), financial literacy is a combination of awareness, knowledge, skill, attitude and behavior necessary to make sound financial decisions and ultimately achieve individual financial well-being. Lusardi (2008), who has examined many aspects of financial literacy and has important studies on the issue in the literature, categorizes financial literacy as basic and advanced financial literacy. While basic financial literacy is defined as the ability to understand interest rates, the effects of inflation and the risk diversification; advanced financial literacy is the ability to take investment and saving decisions, understand the relationship between risk and return, to have knowledge about basic valuation of securities and to understand functioning of bonds, stocks and mutual funds (Lusardi, 2008: 4-7).

Different than other researchers Mak and Braspenning (2012) illustrate financial literacy under the heading of 'the picture of financial literacy' as in Figure 1.

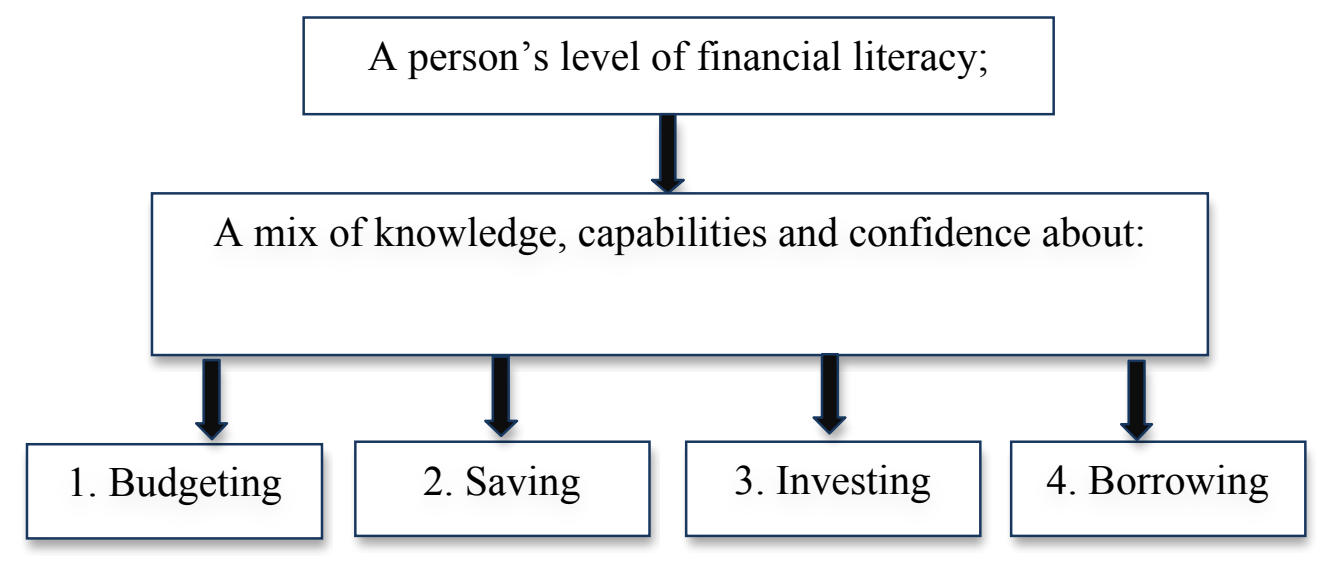

Figure 1. The picture of financial literacy (Mak and Braspenning, 2012: 317)

There are more than one definitions of financial literacy. These definitions have different aspects as well as common points. Remund (2010) summarizing different definitions of financial literacy, classified financial literacy into five categories:

(1) knowledge of financial concepts,

(2) ability to communicate about financial concepts,

(3) aptitude in managing personal finances,

(4) skill in making appropriate financial decisions and

(5) confidence in effective planning for future financial needs (Remund, 2010: 279-281).

The low level of financial literacy is perceived as one of the potential reason for crisis in many developed and developing countries. For this reason, in many countries, especially to increase the financial literacy level of young people, innovation is made in financial education and a number of institutions and associations are being established. 
Jump\$tart Coalition in the USA, Financial Services Authority in England, Russian Trust Fund in Financial Education and Literacy in Russia and Association for Financial Literacy and Accession in Turkey are examples of such establishments. Many countries, to integrate individuals into financial system and to make them conscious of financial issues provide financial literacy trainings to households or employees. Also elective and compulsory courses of financial literacy are added to curriculums in high schools and colleges (Hanna et al., 2010: 29; Jang et al., 2014: 25; Blue et al., 2014: 51). These steps on financial education are early warning and prevention measures for possible crises.

Improving the literacy of individuals in credit card and financial issues will ensure a more efficient use of their credit cards. Especially raising awareness of the youth on these issues, will lead to financially more prosperous life for the individuals who will shape the future of society. Therefore, this study focuses on credit card literacy, which can be considered within the context of financial literacy, of college students. In this context, students are asked about credit card usage behaviors and their credit card literacy is analyzed. Conscious credit card it is important to work for the adoption and use. The study is expected to contribute to the improvement of conscious use of credit cards.

\section{Literature Review}

Most of the studies on credit card in the literature are about credit card usage behaviors. When we look at the studies on credit card usage behaviors of individuals it can be seen that there are different studies investigating factors affecting credit card numbers (Hayhoe et al., 2005) or analyzing the reasons for credit card debts (Norvilitis et al., 2006). In these and similar studies, it is stated that increasing credit card debts with widespread use of credit cards causes psychological problems in college students (Adams and Moore, 2010: 107; Berg et al., 2009). Also it is stated that credit card debts negatively affect academic performances of students (Pinto et al., 2001). However, in these studies there is not any assessment on credit card literacy.

Credit card literacy is defined as having knowledge about basic terms and features of credit card (Kumbarac1, 2010: 5). Although there are very limited numbers of studies on credit card literacy, generally the literature on this issue is considered as part of the financial literacy. Studies conducted to determine financial literacy levels of college students in Turkey generally concluded that students have a low level of financial literacy (Kılıç et al., 2015; Temizel and Bayram, 2011; Alkaya and Yağl1, 2015). In their study on relation between financial literacy and credit card usage, Robb and Sharpe (2009), faced with an unexpected situation after the analysis results. Findings showed student with high level of financial information have higher credit card balances.

Analyzing the relation between level of financial knowledge of college students and their credit card usage behaviors, Robb (2011), conducted a survey with 2.723 students. Study results show significant relations between financial literacy level and credit card usage behaviors. According to findings, students with low level of knowledge would like to use credit card with a higher limit. Students with low level of knowledge rarely pay their credit card debts in full when compared with students who have high level of knowledge. Student with high level of financial knowledge use less cash advances and they pay more than minimum balance when compared with students with low level knowledge. 
Having used a sample of 381 college students Warwick and Mansfield (2000) observed in their study that a majority of the student do not know the interest rate of credit card which they use. At the same time half of the students stated that they don't know the limit and current balance of their credit cards. Mansfield and Pinto (2008) in their study measuring the credit card knowledge of consumers, concluded that respondents have very limited information in understanding credit cards. Although all respondents have information on what a credit card is, no respondent could give a totally correct definition of credit card. It is observed that respondents answered general questions as "I have information" with a very high rate but when asked questions to measure the accuracy of their information the correct answer rate was very low. This shows that individuals participating the survey do not have sufficient knowledge of credit cards.

Moore (2004), in his study with 2.113 college students stated that factors which effect credit card information level are variables such as parents' income, financial support from job/scholarships, and being a business major. The study concluded that students have a high level credit card knowledge, it is thought that this result was due to the fact that most of the interviewed students were from business administration or relevant departments. Wickramasinghe and Gurugamage (2012) investigated demographic and socio-economic factors which affect credit card knowledge. Analysis results show that users with a higher debt ceiling are more literate on personal finance. Also it is observed that married people and individuals with high level of education have more information on credit card system.

\section{Methodology}

This research aimed to measure the credit card literacy level and credit card usage behaviors of undergraduate student. To this end a survey is conducted Gaziantep University. With quota sampling method, which is a non-random sampling method, a total of 720 students from 12 different faculties (around 60 students from each faculty) are included. Students were explained about the aim of survey and they were asked to give the most accurate answer. The survey was conducted in the fall semester of 20152016 academic year on the campus of Gaziantep University.

The questionnaire used in the study consists of three parts. The first part includes demographic information, the second part credit card usage behavior, and the third part contains the credit card literacy test. In credit card literacy test answers contains three options as "True", "False" and "I have no idea".

The scale for credit card literacy is developed by using the survey from the study of Kumbarac1 (2010). Some of the questions from the survey were taken directly while some questions were modified. Also new questions by making use of expert opinions were added to existing questions by the researchers.

\section{Findings}

\subsection{Descriptive Statistics}

Of participated students $348(48,3 \%)$ were female and $372(51.7 \%)$ were male. $172(23,8 \%)$ of these students were at prep class or $1^{\text {st }}$ grade, $210(29.2 \%)$ at $2^{\text {nd }}$ grade, $174(24.2 \%)$ at $3^{\text {rd }}$ grade and $164(22.7 \%)$ were at $4^{\text {th }}$ or upper grades. The average age of the students was 21.38. As the quota sampling method was used faculties are used as groups. These faculties are Communication, Engineering, Fine Arts, Theology, Law, Medicine, Education, Economics and Administrative Sciences, Health Sciences, Art and 
Sciences, Architecture and Dentistry faculties. Among 720 students who interviewed the number of students who use a credit card is 355 , the remaining 365 students stated that they do not use any credit card. Therefore, the analysis was performed on 355 students using a credit card.

Table 1. Number of Credit Cards

\begin{tabular}{lcc}
\hline & Frequency & Percent \\
1 & 264 & 74.4 \\
2 & 72 & 20.3 \\
3 or more & 19 & 5.4 \\
Total & 355 & 100 \\
\hline
\end{tabular}

According to Table 1, of students who use credit card $74.4 \%$ has $1,20,3 \%$ has 2 and $5,4 \%$ has 3 or more credit cards.

Table 2. Years of Using Credit Card

\begin{tabular}{|c|c|c|}
\hline \multicolumn{2}{|c|}{ Number of years } & Percent \\
\hline 1 & 100 & 28.2 \\
\hline 2 & 112 & 31.7 \\
\hline 3 & 54 & 15.3 \\
\hline 4 & 54 & 15.3 \\
\hline 5 or more & 33 & 5.4 \\
\hline Total & 354 & 100 \\
\hline
\end{tabular}

Table 2 shows that majority of students $(59,9 \%)$ who use a credit card are using credit card for less than 2 years. The number of students who use credit card for 5 years or more is quite less $(5,4 \%)$.

Table 3. Monthly Income of Students

\begin{tabular}{lcc}
\hline Monthly Income & Frequency & Percent \\
$0-250 \mathrm{TL}$ & 23 & 6.5 \\
$251-500 \mathrm{TL}$ & 153 & 43.1 \\
$501-750 \mathrm{TL}$ & 91 & 25.6 \\
$751-1,000 \mathrm{TL}$ & 62 & 17.5 \\
$1,001 \mathrm{TL}$ or more & 26 & 7.3 \\
Total & 355 & 100 \\
\hline
\end{tabular}

When we look at the monthly income of the students, a significant portion of the students who use credit card (43,1\%) have a monthly income between TL 251-500. The number of the students with a monthly income of TL 1,001 or over is very low (Table 3).

\subsection{Credit Card Usage Behaviors}

Some behavioral questions were asked in the questionnaire to determine how widespread is the usage of credit cards, of which in recent years usage is increasing and becoming easy, among students and to determine credit card usage behaviors of the students.

Two different questions were asked to identify the frequency of credit card use of students. Firstly, students were asked how much of the monthly expenditure is done by credit card. Students stated $34 \%$ of their monthly expenditure is done by credit card. 
Secondly, when asked amount of expenditure done by credit card, it was observed that average credit card expenditure of students was TL 266 monthly.

Different questions were asked to identify debt payment behaviors of students and results show that average number of months that minimum balance was paid is 4.42 out of last 12 months. Average number of months that less than minimum balance was paid is 1.01. Average number of months in last 12 months which credit card is full paid is determined as 4.87. These results show that students cannot pay their credit card balance in full often. It is observed from the findings that almost half of the year they could pay minimum balance or less. This situation proves that students use credit card unconsciously. Also it explains that students cannot make personal budgets and they cannot form their income-expenditure balance. If the debt payment behavior of the students continues in this way, they may face with financial difficulties in the future.

In order to assess whether students act carefully and prudently while applying for credit cards, the question of "Have you read credit card agreement in detail when you applied for credit card?" is asked. 127 (35.8\%) students answered this question as "Yes" and $228(64.2 \%)$ students replied as "No". These results shows that students don't pay attention to information contained in credit card agreement and that they get credit card unconsciously.

\subsection{Credit Card Literacy Levels}

In credit card literacy test right answers to the questions were rated as "1" point while wrong answers and "no idea" answers were rated as " 0 " points. Credit card literacy score of the students is calculated as total number of right answers divided by total number of questions. Accordingly, the credit card literacy level of the participating students is calculated as $43 \%$.

Credit card literacy scores of participating students according to their different demographic features are summarized in Table 4.

Table 4. Average Credit Card Literacy Scores According to Demographics

\begin{tabular}{llc}
\hline \multirow{3}{*}{ General Literacy Level } & & Percentage score (\%) \\
\hline Gender & Female & 43 \\
& Male & 41 \\
& Communication & 44 \\
\hline Faculty & Engineering & 41 \\
& Fine Arts & 47 \\
& Theology & 48 \\
& Law & 35 \\
& Medicine & 46 \\
& Education & 35 \\
& Econ. \& Admin. Sciences & 37 \\
& Health Sciences & 42 \\
& Art and Sciences & 52 \\
& Architecture & 45 \\
& Dentistry & 46 \\
& I know exactly & 42 \\
\hline Do you know the interest & I have an idea & 48 \\
rate of your credit card? & I have no idea & 42 \\
& Yes & 42 \\
\hline Did you read credit card & No & 46 \\
contract? & & 42 \\
\hline
\end{tabular}


Credit card literacy score of female students is calculated as $41 \%$ while the same score for male students is $44 \%$. When look at the scores of student according to faculties which they study at, the highest score (52\%) belongs Faculty of Health Sciences and the lowest score (35\%) belongs to Theology and Medicine faculties. Credit card literacy score of students who know the interest rate of their credit card $(48 \%)$ is higher than ones who don't know $(42 \%)$ or have no idea $(42 \%)$. Credit card literacy score of students who have read credit card agreement $(46 \%)$ is higher than students who have not read the agreement (42\%). Although the results give some ideas numerically, to comment them statistically some statistical analysis have been conducted.

\subsubsection{The Relationship between Gender, Reading Contract and Credit Card Literacy Levels}

To determine whether there is a difference between credit card literacy and gender and reading of credit card agreement of students, $t$ test with independent sampling was conducted and results are shown in Table 5.

Table 5. T Test: The Relationship between Gender, Reading Contract and Credit Card Literacy Levels

\begin{tabular}{cccccc}
\hline & \multicolumn{2}{c}{ Gender } & \multicolumn{2}{c}{ Reading Contract } \\
\hline & & Female & Male & Yes & No \\
\hline Credit & $\mathrm{N}$ & 126 & 228 & 126 & 228 \\
Card & $\bar{x}$ & 0.412 & 0.442 & 0.459 & 0.417 \\
Literacy & $\mathrm{T}$ & -1.883 & & 2.676 & \\
Levels & $\mathrm{P}$ & .061 & & .008 & \\
\hline
\end{tabular}

When the relation between gender and credit card literacy of the students is examined, it can be seen that credit card scores differ significantly according to gender $(p<.10)$. Analysis results show that scores of females are lower than males. Likewise, studies on financial literacy in the literature also indicate that males have higher financial literacy level than males (Fonseca et al., 2012; Hanna et al., 2010; Chen and Volpe, 1998; Chen and Volpe, 2002; Kılıç et al, 2015). Similar results are observed for credit card literacy.

A significant difference is observed between credit card literacy levels and whether credit card agreement is red in detail $(p<.05)$. Analysis results show that students who get a credit card consciously have a higher level of credit card literacy.

\subsubsection{The Relationship between Faculties and Credit Card Literacy Levels}

In order to determine whether credit card literacy level vary by faculties, ANOVA test is conducted. Test results are shown in Table 6. Results indicate that there are significant differences between credit card literacy level of students studying in different faculties $(\mathrm{p}<.05)$.

Table 6. ANOVA: The Relationship between Faculties and Credit Card Literacy Levels

\begin{tabular}{cccc}
\hline & \multicolumn{3}{c}{ Faculties } \\
\hline & $\mathrm{N}$ & $\mathrm{F}$ & $\mathrm{P}$ \\
\hline Credit Card Literacy Levels & 354 & 4.148 & .000 \\
\hline
\end{tabular}


Tukey test is conducted as post-hoc analysis to define differences between credit card literacy of faculty students. Test results are summarized in Table 7. To save space in table only significant differences are shown.

According to Tukey test results there are significant differences between students of Health Sciences and Medicine faculties and students of other faculties in terms credit card literacy levels. An early study done at the same university by Kılıç et al. (2015) on financial literacy also concluded that financial literacy levels of students vary by their faculties.

Table 7. Tukey Test: The Relationship between Faculties and Credit Card Literacy Levels

\begin{tabular}{llrrl}
\hline (I) Faculties & $(\mathbf{J})$ Faculties & Mean Difference (I-J) & Std. Error & \multicolumn{1}{l}{ Sig. } \\
\hline Communication & Health Sciences & $-0.112^{* *}$ & 0.035 & 0.066 \\
Engineering & Medicine & $.1244^{*}$ & 0.028 & 0.001 \\
Fine Arts & Medicine & $.1345^{*}$ & 0.037 & 0.018 \\
Theology & Health Sciences & $-0.171^{* *}$ & 0.053 & 0.058 \\
Law & Medicine & $.1194^{*}$ & 0.030 & 0.004 \\
Health Sciences & Medicine & $-.1736^{*}$ & 0.036 & 0.000 \\
Art and Sciences & Medicine & $-.1050^{*}$ & 0.031 & 0.035 \\
Architecture & Medicine & $-0.116^{* *}$ & 0.037 & 0.086 \\
Education & Health Sciences & $-.1481^{*}$ & 0.044 & 0.039 \\
\hline
\end{tabular}

* The mean difference is significant at the 0.05 level.

**The mean difference is significant at the 0.10 level.

\subsubsection{The Relationship between Credit Card Usage Frequency, Regular Debt Payment Habit and Credit Card Literacy Levels}

To determine whether there is a relation between frequency of credit card usage (portion of expenditures done by credit card in total monthly expenditure) and credit card literacy levels of students, correlation analysis is conducted. According to analysis results, shown in Table 8, statistically significant and positive relationship between two variables is observed, but the correlation coefficient between the variables $(0.123)$ is significantly lower. Consequently, as the frequency of credit card usage of students increases their level of credit card literacy also increases.

Table 8. Correlation: The Relationship between Credit Card Usage Frequency and Credit Card Literacy Levels

\begin{tabular}{llcc}
\hline & & $\begin{array}{c}\text { Credit Card Literacy } \\
\text { Level }\end{array}$ & $\begin{array}{c}\text { Credit Card Usage } \\
\text { Frequency }\end{array}$ \\
\hline Credit Card & Pearson &, $123^{*}$ & 1 \\
Usage & Correlation & & \\
Frequency & Sig. (2-tailed) & 0,021 & 355 \\
& $\mathrm{~N}$ & 354 & \\
\hline
\end{tabular}

*Correlation is significant at the 0.05 level (2-tailed).

Likewise, to determine whether there is a relation between regular debt payment habit (number of months in which they paid credit card balance in full in last 12 months) and credit card literacy levels of students, correlation analysis is conducted and the results are shown in Table 9. 
Table 9. Correlation: The Relationship between Regular Debt Payment Habit and Credit Card Literacy Levels

\begin{tabular}{llcc}
\hline & & $\begin{array}{c}\text { Credit Card } \\
\text { Literacy Level }\end{array}$ & $\begin{array}{c}\text { Regular Debt } \\
\text { Payment Habit }\end{array}$ \\
\hline Regular Debt & Pearson Correlation &, $204^{* *}$ & 1 \\
Payment Habit & Sig. (2-tailed) & .000 & 355 \\
& $\mathrm{~N}$ & 354 & 354 \\
\hline
\end{tabular}

**Correlation is significant at the 0.01 level (2-tailed).

According to analysis results, statistically significant and positive relationship between regular debt payment habit and credit card literacy level of students is observed. But the correlation coefficient (0.204) is low again. Accordingly, as the debt payment habit of students increases their level of credit card literacy also increases.

\section{Conclusion and Discussion}

Credit card usage continues to increase day by day. Indeed, in all of their expenditures individuals are willing to use a credit card or debit card. In such an environment conscious use of credit cards and having sufficient information about credit cards are very important. Especially for the younger generations like college students, who will shape the future, to be conscious in the use of credit cards and financial issues is a key issue for the welfare of both the society and students. Therefore, this study reveals the current profile of college students and constitutes a perspective to improve training of young people in financial matters.

In this study, which aims to determine level of credit card literacy of college students, credit card literacy level of the students is calculated as $43 \%$. The low level of credit card literacy shows that students do not have sufficient information about credit cards they are using. Among the findings of the study are; students who use credit card generally have low-income, one third of monthly expenditures of students are done by credit card and generally credit card balances are not paid in full.

Credit card literacy of college students varies by gender, faculty and readability of the credit agreement. Results of the study are similar to previous studies conducted on financial literacy (Luksander, 2014; Chen and Volpe, 2002; Beal and Delpachitra, 2003; K1lıc et al, 2015). Although credit card literacy scores of the college students are low, as frequency of credit card usage and regular debt payment habit increases literacy level also increases. In terms of credit card literacy, it is necessary to generalize conscious usage of credit card. Therefore, trainings should be organized for households and young people about credit card literacy and conscious usage of credit card. Also courses on financial literacy including credit card issues or personal finance courses may be added to university curriculum. 


\section{References}

Adams, Troy, \& Moore, Monique (2010). "High-Risk Health and Credit Behavior Among 18- To 25-Year-Old College Students", Journal of American College Health, 101-108.

Alkaya, Aylin, \& Yağlı, İbrahim (2015). "Finansal Okuryazarlık-Finansal Bilgi, Davranış ve Tutum: Nevşehir Hacı Bektaş Veli Üniversitesi İIBF Öğrencileri Üzerine Bir Uygulama", Uluslararası Sosyal Araştırmalar Dergisi, 8(49), 585599.

Beal, Diana \& Delpachitra, Sarath (2003). "Financial Literacy among Australian University Students", Economic Papers, 22(1), 65-78.

Berg, C., Sanem, J., Lust, K., Ahluwalia, J., Kirch, M., \& An, L. (2009). "HealthRelated Characteristics and Incurring Credit Card Debt as Problem Behaviors Among College Students", The Internet Journal of Mental Health, 6(2).

Berlin, Mitchell, \& Mester, Loretta (2004). "Credit Card Rates and Consumer Search", Review of Financial Economics, 13, 179-198.

Blue, Levon, Grootenboer, Peter \& Brimble, Mark (2014). "Financial Literacy Education in the Curriculum: Making the Grade or Missing the Mark?", International Review of Economics Education, 16, 51-62.

Borzekowski, Ron, Kiser, Elizabeth, \& Ahmed, Shaista (2006). Consumers' Use of Debit Cards: Patterns, Preferences, and Price Response, Federal Reserve Board. Washington: Finance and Economics Discussion Series. Divisions of Research \& Statistics and Monetary Affairs.

Chen, Haiyang \& Volpe, Ronald (2002, August). "Gender Differences in Personal Financial Literacy among College Students", Financial Services Review, 11, 289-307.

Chen, Haiyang, \& Volpe, Ronald P. (1998). "An Analysis of Personal Finance Literacy among College Students", Financial Services Review, 7(2), 107-128.

Fonseca, R., Mullen, K., Zamarro, G., \& Zissimopoulos, J. (2012). "What Explains The Gender Gap in Financial Literacy? The Role of Household Decision Making", The Journal of Consumer Affairs, 90-106.

Hanna, Michael, Hill, Robert, \& Perdeu, Grady (2010). "School of Study and Financial Literacy", Journal of Economics and Economic Education Research, 11(3), 2937.

Hayhoe, Celia Ray, Leach, Lauren, Allen, Myria W., \& Edwards, Renee. (2005). "Credit Cards Held by College Students", Financial Counseling and Planning, 16(1), 1-10.

Jang, Kyungho, Hahn, Jinsoo \& Park, Hyung Joon (2014). "Comparison of Financial Literacy Between Korean and U.S. High School Students", International Review of Economics Education, 16, 22-38.

Kılıç, Yunus, Ata, Hacı Ali, \& Seyrek, İbrahim (2015, April). "Finansal Okuryazarlık: Üniversite Öğrencilerine Yönelik Bir Araştırma", Muhasebe ve Finansman Dergisi (66), 129-150. 
Luksander, Alexandra, Beres, D., Huzdik, K. \& Nemeth, E. (2014). "Analysis of the Factors that Influence the Financial Literacy of Young People Studying in Higher Education", Public Finance Quarterly, 220-241.

Lusardi, Annamaria (2008). Financial literacy: an essential tool for informed consumer choice? (No. w14084). National Bureau of Economic Research.

Kumbarac1, Okan (2010). Credit Card Literacy among University Students, Master Thesis. İstanbul: Boğaziçi University.

Mak, V., \& Braspenning, J. (2012). "Errare humanum est: Financial literacy in European consumer credit law". Journal of consumer policy, 35(3), 307-332.

Mansfield, Phylis, \& Pinto, Mary Beth (2008). "Consumer Vulnerability and Credit Card Knowledge among Developmentally Disabled Citizens", The Journal of Consumer Affairs, 42(3), 425-438.

Moore, Rosita (2004). Credit Card Knowledge, Attitudes, and Practices of College Students. Lubbock, Texas: Texas Tech University, Doctoral Dissertation.

Norvilitis, Jill, Merwın, Michelle, Osberg, Timothy, Roehlıng, Patricia, Young, Paul, \& Kamas, Michelle (2006). "Personality Factors, Money Attitudes, Financial Knowledge, and Credit-Card Debt in College Students", Journal of Applied Social Psychology, 36(6), 1395-1413.

Özkan, Canan (2014). Türkiye'de Kredi Kartı Kullanıcı Profili ve Davranış Analizi. Ankara: Türkiye Cumhuriyet Merkez Bankası Bankacılık ve Finansal Kuruluşlar Genel Müdürlüğ̈̈.

Pinto, Mary Beth, Parente, Diane, \& Palmer, Todd Starr (2001). "College Student Performance and Credit Card Usage", Journal of College Student Development, 42(1), 49-58.

Remund, D. L. (2010). "Financial literacy explicated: The case for a clearer definition in an increasingly complex economy". Journal of Consumer Affairs, 44(2), 276295.

Robb, Cliff A. (2011). "Financial Knowledge and Credit Card Behavior of College Students", Journal of Family and Economic Issues, 32, 690-698.

Robb, Cliff A., \& Sharpe, Deanna (2009). "Effect of Personal Financial Knowledge on College Students' Credit Card Behavior", Journal of Financial Counselling and Planning, 20(1), 25-43.

Temizel, Fatih, \& Bayram, Fatih (2011). "Finansal Okuryazarlık: Anadolu Üniversitesi İktisadi ve İdari Bilimler Fakültesi Öğrencilerine Yönelik Bir Araştırma", Cumhuriyer Üniversitesi İktisadi ve İdari Bilimler Dergisi, 12(1), 73-86.

Warwick, Jacquelyn, \& Mansfield, Phylis (2000). "Credit Card Consumers: College Students' Knowledge and Attitude", Journal of Consumer Marketing, 17(7), 617-626.

Wickramasınghe, Vathsala, \& Gurugamage, Anurudh. (2012). "Effects of Social Demographic Attributes, Knowledge about Credit Cards and Perceived Lifestyle Outcomes on Credit Card Usage", International Journal of Consumer Studies, $36,80-89$. 